\title{
Historical Overview of Jus Cogens Norms, Their Applicability by International Courts and Necessity for Unification
}

\author{
Valeza Ukaj-Elshani, Ph.D. Candidate ${ }^{1}$ \\ Prishtina, Republic of Kosova \\ valeza.ukaj@uni-pr.edu
}

\begin{abstract}
The principal aim of this paper is the need for standardization of jus cogens norms, which besides their definition by the Vienna Convention on the Law of Treaties have been further developed by international courts. The paper is divided in four parts that include the characterization of jus cogens norms, their development in the early history of international law, the development of these norms by international and regional courts and ends with the need of unification of jus cogens norms.

A general conclusion thus can be drawn. The international courts, in order not to become inclined to use controversial terms of jus cogens norms, necessitate for a harmonized system and standardization of these norms in order to further develop jus cogens norms. Thus, the fulfillment of these norms through standardization allows us to think that one day all international wrongful acts will become at some point world-wide derogatory.

Keywords: jus cogens norms, Vienna Convention on the Law of the Treaties, international law, standardization, unification, non-derogable.

1 The author is a Ph.D. Candidate at Clemson University, South Carolina, USA. Has finished the LLM degree at Catholic University of Leuven (KUL), Belgium. She is working as a teaching assistant at Law Faculty of the University of Prishtina and has worked as a Graduate Research Assistant at Clemson University.
\end{abstract}


Valeza Ukaj-Elshani. Historical Overview of Jus Cogens Norms,

Their Applicability by International Courts and Necessity for Unification

\section{Concept and application of jus cogens norms}

Jus cogens norms ${ }^{2}$ are part of international law. As such these principles are compelling as some other norms of international law; however, unlike the others these are binding towards all states.

Though there is no specific list of categorizing international law sources in terms of importance, according to Article 38 of the International Court of Justice (ICJ), whose function is to decide in accordance with international law, the Court applies sources as: international conventions, whether general or particular, establishing rules expressly recognized by the contesting states, international custom, as evidence of a general practice accepted as law, the general principles of law recognized by civilized nations and judicial decisions and the teachings of the most highly qualified publicists of the various nations for the determination of rules of law. The statute of international law classifies international custom as a second source of international law, confirmed thereby by the ICJ in the case of Nicaragua v. United States of America [6].

When speaking about general principles of law not all international customs can reach at the level of jus cogens norms, hence as rights as international community accepts them as binding. This means that some states accept as customary law only a set of specific norms however the others do not accept them as customary law. In fact, these set of international law sources exist, and they make the so-called "a body of binding jus cogens" norms [9]. Nonetheless, the criterion of jus cogens norms consists in the fact that they do not exist to satisfy the individual interest but the interest of the entire international community [49].

Jus cogens norms are considered to be part of general principles of international law, which states accept as norms from which no derogation is allowed. In this regard there have been arguments between the international community, namely the drafters ${ }^{3}$ of the 1969 Vienna Convention on the Law of Treaties (VCLT) for several years until when, at the Vienna Conference in 1969 it was agreed that Article 53 of the VCLT, expressly confirmed jus cogens norms of general international law as a norm accepted and recognized by the international community of States from which no derogation is permitted, and that any treaty which is in force, shall be void if at the time of its conclusion conflicts with a peremptory norm of general international law [47]. As such, states are bound by customary international law to respect these rules regardless of their codification through their treaties or domestic laws and, and such rules prevail over any international agreement and other rules of international law that are contrary to them.

${ }^{2}$ In this paper I will use the phrase jus cogens instead of "peremptory", which has the same meaning within this category of norms. However, the literal translation of this latin phrase is "compelling law".

3 The drafter of the Vienna Convention on the Law of Treaties is the International Law Commission. International Law Commission was established by the United Nations General Assembly in 1948 for the promotion of the progressive development of international law and its codification. 
Recognition of jus cogens norms was confirmed again in the 1986 Vienna Convention on the Law of Treaties between States and International Organizations or between International Organizations [47]. The purpose of these rules is to be used beyond the treaty law, in particular in the responsibility of the domestic law of the state. Here, the International Law Commission (ILC) which is responsible for the promotion and progressive development of international law and its codification [36] proposed the notion of international crimes resulting from the breach by a state of an international obligation "essential for the protection of fundamental interests of the international community", which is in fact closely linked to the doctrine of international jus cogens.

As is stated below which norms are considered to be jus cogens, it is important to note that Article 64 of VCLT denotes that if a new peremptory norm of general international law emerges, any existing treaty which is in conflict with that norm becomes void and null. This definition leaves room for further understanding that international law as a law that is in a constant state of evolution can further develop new norms.

\section{Development of jus cogens norms}

\section{"The law of nations is part of the law of the land." [3]}

Generally, normative rules within national level are considered to go through a hierarchy of sources which include constitution(s), law(s) and regulation(s). Therefore, a law may not contradict or conflict the constitution, and a regulation may not contradict a law, or vice-versa the constitution.

On the other side, the development of jus cogens norms traces upon the idea that certain categories of law that derive from reasoning of long humanity usage, in this case natural law should prevail over the ones which are derived through legislative process. This discerns that jus cogens norms are norms that have not developed in the twentieth century, but to a certain extent are norms that have been known since the ancient times of societal development.

Natural law as part of the jurisprudence of the broader tradition of thought is associated with Greek philosophy, namely the Greek philosophers known as Augustine, Aquinas, who began to apply the idea of natural law in international relations, in war and peace [28]. For theologians of the sixteenth century, for Hugo Grotius and other classical writers it notes that there were several 'specific' principles which amounted to the level of natural jus necessarium (necessary natural law). Grotius emphasized that the principles of natural law were so immune that the Lord himself could not change them [14]. In fact, natural law was interpreted as a necessary law where all states are obliged to respect it [49].

Since then, the classical publicists and theologians as Hugo Grotius, Name de Vattel, and Christian Wolf, wrote the difference of jus scriptum (binding law) and jus dispositivum (voluntary law) to differentiate consensual agreements between states from 
the 'binding' principles of international law that is binding upon on all states regardless of their conscience point of consent [14]. A wide-ranging article of jus cogens was given by Alfred von Verdross, who argues that "no judicial order can ... admit treaties between juridical subjects, which are obviously in contradiction to the ethics of a certain community" [49], thereby emphasizing the "natural law" or "moral" foundation of jus cogens norms. In fact, according to Verdross every legal order "has its roots in the ethics of a certain community" [49] and it "cannot be understood apart from its moral basis" [49].

Jus cogens notion has been a subject of debate throughout the first half of the twentieth century. In fact, without expressly referring to the notion of jus cogens, a number of writers during the 1920's have discussed the existence of such superior norms when advancing claims that treaties, like contracts, should be void if contravening certain fundamental rules [46].

These theories and other theories of positivism began to develop until the twentieth century, when jus cogens norms were confirmed in 1969 of the VCLT. Thus, since then jus cogens norms have received a widespread acceptance by a large number of international, regional, municipal courts. ${ }^{4}$ It should be noted also that, some peremptory norms are enforceable not only against states but also against individuals, such as the prosecution of Leaders at Nuremberg [15] and Tokyo which offered compelling evidence that international law did, indeed, impose substantive limits on the invocation of state sovereignty as a shield for officials accused of crimes against humanity [15].

Although the ILC as drafters of the VCLT did not list explicitly jus cogens norms, however, in their report were included some of the most worldwide known norms such as: (1) Principles of the Charter of the United Nations unlawful use of force; (2) International laws that prohibit the performance of any other act criminal under international law; and (3) International laws that oblige States to co-operate in the suppression of certain acts such as trade in slaves, piracy or genocide. Given the fact that a lot of criticisms were

4 See, e.g., 1934 Oscar Chinn Case, Judge Schücking's influential dissent stated that neither an international court nor an arbitral tribunal should apply a treaty provision in contradiction to bonos mores. Oscar Chinn Case, 1934 P.C.I.J. (ser. A/B) No. 63, at 149-50 (Dec. 12) (Schücking, J., dissenting); Siderman de Blake v. Republic of Arg., 965 F.2d 699 (9th Cir. 1992) (recognizing torture as a jus cogens violation); Case T-115/94 Opel Austria GmbH v. Council [1997] ECR II-39, Case C-162/96 Racke v. Hauptzollamt Mainz [1998] ECR I-3655 (in both of the cases, Community courts have explicitly relied on customary international law to test the validity of acts of EU institutions); Suresh v. Canada (Minister of Citizenship and Immigration), [2002] S.C.R. 3, 40-41, 2002 SCC 1 (Can.) (stating that the prohibition on torture "cannot be easily derogated from"); Armed Activities on the Territory of the Congo, Jurisdiction of the Court and Admissibility of the Application (Dem. Rep. Congo v. Rwanda) (Judgment of Feb. 3, 2006), available at http://www.icj-cij.org/docket/files/126/10435. pdf (recognizing genocide as a violation of jus cogens); Military and Paramilitary Activities in and Against Nicaragua (Nicaragua. v. United States), 1986 I.C.J. 14, 100 (recognizing the prohibition on the use of force in international law as jus cogens). 
addressed in this direction for the exclusion of specific norms within jus cogens norms, again it can be concluded that almost all states recognized prima facie the existence of jus cogens in international law and it was on this basis that Article 53 of the Vienna Convention was adopted. ${ }^{5}$

With particular emphasis various international and domestic courts have consistently given and contributed to further development of jus cogens norms. There is a general agreement accepted by the international community which could list the jus cogens norms as the following: the prohibition of genocide, prohibition of torture, prohibition of slavery and slave trade, the prohibition of war of aggression or crimes against humanity; prohibition of piracy; prohibition of racial discrimination, denial of the right to self-determination [26]. Principally, states which allow one of these 'international crimes', are at the same time in breach of international law, respectively jus cogens norms.

These 'international crimes' expressly prohibited which are envisaged under jus cogens norms appear in numerous instruments of universal application. ${ }^{6}$

\section{Typical examples of international instruments}

Genocide although prohibited by jus cogens norms, is prohibited also under 1948 United Nations Convention against Genocide [35] and the Rome Statute of the International Criminal Court [43].

Torture not only guaranteed by Article 5 of 1949 Universal Declaration of Human Rights [43], Article 7 of 1966 United Nations International Covenant on Civil and Political Rights [39], Article 3 of 1950 European Convention on Human Rights [8] and Article 4 of 2000 Charter of Fundamental Rights European Union [12], but the prohibition of torture is now prohibited under the 1949 Geneva Conventions for the protection of war crimes [19], under 1984 United Nations General Assembly Convention against Torture and Other Cruel, Inhuman or Degrading Treatment or Punishment [32] and under Rome Statute of the International Criminal Court [43].

Slavery is guaranteed by Article 4 of 1949 Universal Declaration of Human Rights [44], Article 8 of 1966 United Nations International Covenant on Civil and Political Rights [39].

${ }^{5}$ Report of the Sixth Committee to the General Assembly during the eighteenth period of sessions (1963), UN Doc. A/5601.

6 The 1948 Universal Declaration of Human Rights, G.A Res. 217A, U.N. GAOR 3rd Comm., as a non binding instrument is considered to be customary international law and binding among all states whether or not they have endorsed it to their national legislation; the 1949 Geneva Conventions for protection of war crimes is considered to be part of the customary international law (Art. 86 Simic case ICTY); the International Covenant on Civil and Political Rights of 1966; General Assembly resolution 3452/30 of 9 December 1975 on the Protection of All Persons from Being Subjected to Torture and Other Cruel, Inhuman or Degrading Treatment or Punishment. 
Crimes against humanity are guaranteed by 1968 Convention on the non-applicability of statutory limitations to war crimes and crimes against humanity [34] and by the Rome Statute of the International Criminal Court [32].

Piracy is guaranteed by Articles 100, 107 and 110 of the 1982 Convention on the Law of the Sea [33].

Racial discrimination is guaranteed by Article 2 of the 1949 Universal Declaration of Human Rights [44], Article 2 of 1966 International Covenant on Civil and Political Rights [39], Article 2 of 1966 International Covenant on Economic, Social and Cultural Rights [40], 1965 International Convention on the Elimination of All Forms of Racial Discrimination [38] and Rome Statute of the International Criminal Court [32].

Self-determination is guaranteed by Article 1 of the United Nations Charter [36], Article 1 of 1966 International Covenant on Civil and Political Rights [39], Article 1 of 1966 International Covenant on Economic, Social and Cultural Rights [40] and 1960 Declaration on the Granting of Independence to Colonial Countries and Peoples [36].

Overall, the effect of jus cogens and the numerous convention that prevent these criminal acts has been in the sense of invalidating every and any legislative, administrative or judicial measure that, at the level of domestic law of the States, attempts to authorize or tolerate torture, [11] and all other acts contrary to international law.

Overall, the prevention of these criminal acts has gradually extended its vertical dimension in almost all national democratic legislations. However, in some cases it remains to the margin of the states to assess its implementation in accordance with the international law.

\section{Development of jus cogens norms in the international legal order}

By postulating a hierarchy of rules rather than defining the basis of their content and underlying its values, jus cogens norms has made its way into the very heart of almost all national democratic legal systems.

It is true that the ILC did not include any specific examples of jus cogens norms, reasoning that "the mention of some cases of treaties void for conflict with a rule of jus cogens might ... lead to misunderstanding as to the position concerning other cases not mentioned in the article". However, if the Commission was to attempt to draw up, even on a selective basis, a list of rules of international law which are to be regarded as having the character of jus cogens, it might find itself engaged in a prolonged study of matters which fall outside the scope of the present articles [48]. Nevertheless, jus cogens norms are evolving norms which continue to evolve by the international practice and opinio juris of international law, which if consistent with nearly all state practice then they, will emerge gradually. 
As far as international case laws are concerned, international tribunals, regional and national courts have considerably contributed to the development of the jus cogens norms through years. In this part there will be an elaboration how the Permanent Court of International Justice has developed this notion, to continue with the International Court of Justice, the International Criminal Tribunal for the former Yugoslavia, the United States Court of Appeals, and the Inter-American Court.

The first judgments set by the Permanent Court of International Justice (PCIJ) to confirm the earliest application of peremptory norms as non-derogable is considered the Wimbledon case. Though the case relates to disputes arisen before the adoption of the Vienna Convention on the Law of the Treaties, it is seen that since then the Court relied on jus cogens notion. In fact, PCIJ declared in the Wimbledon case [29] that sovereignty is not inalienable. Indeed, sovereignty cannot be claimed as a barrier to the binding nature of jus cogens obligations [2]. The case concerned a dispute between the United Kingdom and Germany in 1923, where the Court stated that sovereignty cannot be an excuse to derogate from peremptory norms [29]. The situation in this case regards the Treaty of Versailles (1919) and German sovereignty. The British ship, the S. S. Wimbledon (owned by a French company) attempted to carry munitions and supplies to Poland as they fought a war with Russia. Germany refused the boat access through the Kiel Canal, which is in German territory.

The applicants submitted a request before the court on the grounds of wrongfulness by German authorities when they refused access to the ship. The Neutrality Orders issued by Germany, were defined as inconsistent with Article 380 of the Treaty of Versailles, which states that: "The Kiel Canal and its approaches shall be maintained free and open to the vessels of commerce and war of all nations at peace with Germany on terms of entire equality"; therefore, the applicants ordered damages for lost of time and money in the transport of the goods.

The court while establishing its reasoning over this judgment stated that:

“...it declines to see in the conclusion of any Treaty by which a State undertakes to perform or refrain from performing a particular act an abandonment of its sovereignty. No doubt any convention creating an obligation of this kind places a restriction upon the exercise of the sovereign rights of the State, in the sense that it requires them to be exercised in a certain way." [29]

Since Article 380 of the Treaty of Versailles lays down that the Kiel Canal shall be maintained free and open to the vessels of commerce and war of all nations at peace with Germany, from the foregoing matters it appears clearly established that Germany did not in consequence of her neutrality, incur the obligation to prohibit the passage of the "Wimbledon" through the Kiel Canal, but, on the contrary, was entitled to permit it [29]. Therefore, the court ruled in favor of the applicants, and ordered Germany, which wrongfully refused passage through the Canal to the vessel "Wimbledon" that it is responsible for the loss occasioned by this refusal and must compensate the French Government. 
In conclusion of this case we see that Treaty making is an attribute of sovereignty, whereas Germany in this case and all states in general, although sovereign is without doubt bound to the treaties they sign it.

Another case, that condemned about the general principles of law rendered by PCIJ was the Oscar Chinn Case. The case concerned a dispute which was arisen between two governments (Belgium and United Kingdom) with regard to a claim made by the Government of the United Kingdom in respect of loss and damage alleged to have been sustained by Mr. Oscar Chinn, a British subject, as the result of certain measures taken and applied by the Belgian Government in connection with the limited liability Company "UNATRA" in relation to fluvial transport on the waterways of the Belgian Congo [20]. As the question put by the Government of United Kingdom addressed to the Court concerned the Belgium obligations which were in conflict with the Government of the United Kingdom under the Convention of Saint Germain and that Mr. Chinn had suffered damage on account on the non-observance by the Belgian Government of its international obligations towards the Government of the United Kingdom, and that the Belgian Government is accordingly liable to make reparation to the Government of the United Kingdom. In addition the Government of the United Kingdom relied on general principles of international law and on the obligation incumbent upon all States to respect the vested rights of foreigners in their territories, and that it is this obligation which the Belgian Government is alleged to have infringed in regard to Mr. Chinn [20]. Yet, the Court based on the Convention of Saint-Germain 1919 and general principles of international law decided that, the Belgian Government did not violate any international legal obligations to the United Kingdom.

An important conclusion in this case is the dissenting opinion of Judge Schücking's who stated that neither an international court nor an arbitral tribunal should apply a treaty provision in contradiction to bonos mores. In addition, he stated that

"the League of Nations would have already embarked on the codification of international law if it were not possible, even today, to create a jus cogens, the effect of which would be that, once States have agreed on certain rules of law, and have also given an undertaking that these rules may not be altered by some only of their number, any act adopted in contravention of that undertaking would be automatically void." [47]

Albeit the Court did not stop on the particular norm of jus cogens, it seems that the dissenting opinion of Judge Schücking, clarified further the jus cogens notion by postulating that the agreement of states on certain rules cannot be altered by acts which are in breach to the established rules, otherwise such rules would be null and void.

Jus cogens concept was further confirmed by the ICJ in the case Judgment on Preliminary Objections in Armed Activities on the Territory of the Congo (Congo v. Rwanda), however it did not clarify jus cogens legal status or to specify any criteria for identifying peremptory norms [5]. The case concerned about the Democratic Republic of Congo (hereinafter - DRC) which brought a suit to the ICJ against Rwanda on the ground 
that Rwanda allegedly was involved in and supported variety military activities against the DRC territory. DRC has signed with Congo nine treaties (one of the main treaties were: 1948 United Nations Convention against Genocide, and 1965 International Convention on the Elimination of All Forms of Racial Discrimination), which contained in the jurisdictional clause that in any event the dispute must be resolved through ICJ.

When the case was brought to the ICJ, DRC's argument was based on that that Rwanda's withdrawal of its reservation to Article 9 of the Genocide Convention is invalid, and hereby the Court must confirm it. The Court's argument related to the fact that a dispute relates to compliance with a norm having a character of jus cogens, (when it assured with regard to the prohibition of genocide), cannot of itself provide a basis for the jurisdiction of the Court to entertain that dispute. Under the Court's Statute that jurisdiction is always based on the consent of the parties [5, 31].

DRC's elaboration that Rwanda's reservation is invalid, maintains that Genocide Convention has "the force of general law with respect to all States", in as much as it contains norms of jus cogens. However, the Court reaffirmed that "the principles underlying the Genocide Convention are principles which are recognized by civilized nations as binging upon States, even without any conventional obligation" and that a consequence of that conception is "the universal character both of the condemnation of genocide and of the co-operation required 'in order to liberate mankind from such an odious scourge' (Preamble to the Convention)" [5, 49-51].

The other argument of DRC was based on jus cogens retroactive effect in the overriding interest of humanity that Rwanda has failed to comply, the Court recalled that Article 4 of the VCLT provides for non-retroactivity of its Convention, because in the case at hand, both parties acceded to Genocide Convention and Convention on Racial Discrimination before they acceded to VCLT. In this part, the Court also stated that the rules contained in the VCLT (are not applicable), save in so far as they are declaratory of customary international law. Therefore, it concluded that it has no jurisdiction to entertain the Application; the Court is not required to rule on its admissibility.

In all of the counter-arguments, Rwanda sought to object its arguments on the grounds that it has entered reservations, or the treaties did not apply to the actual matter, or it was not party to these treaties. Nevertheless, the ICJ in evaluating this case deliberated that States whether or not parties to the jurisdiction of the Court are required to fulfill their obligations under the United Nations Charter and other rules of international law, including international humanitarian and human rights law, and they remain responsible for acts attributable to them which are contrary to international law. Consequently, the Court found that it has no jurisdiction to entertain the Application filed by the DRC.

The other case, Nicaragua v. United States of America, comprised two countries the U.S. and Nicaragua, where Nicaragua argued that the U.S. by supporting operations and activities of a paramilitary rebel group has violated the international law rule prohibiting the use of force between states. After the question was put in court, the ICJ 
relied upon the jus cogens character of the prohibition of the international law rule (use of force), as a fortiori argument establishing its status as a rule of customary international law [6]. That said, the ICJ explicitly confirmed jus cogens norms as accepted doctrine of international law $[6,14]$. At the same time, here the Court specified that "the prohibition of the use of force" is a concrete example within the principle of international law that has the character of jus cogens norms [6, 14].

ICJ in the case Belgium v. Senegal confirmed again the jus cogens nature of prohibition of torture, by postulating that:

"...the prohibition of torture is part of customary international law and it has become a peremptory norm (jus cogens). That prohibition is grounded in a widespread international practice and on the opinio juris of States. It appears in numerous international instruments of universal application (in particular the 1948 Universal Declaration of Human Rights, the 1949 Geneva Conventions for the protection of war victims; the 1966 International Covenant on Civil and Political Rights; General Assembly resolution 3452/30 of December 9, 1975 on the Protection of All Persons from Being Subjected to Torture and Other Cruel, Inhuman or Degrading Treatment or Punishment), and it has been introduced into the domestic law of almost all States; finally, acts of torture are regularly denounced within national and international fora." [28]

In this judgment the ICJ expressly acknowledged that the prohibition of torture is part of customary international law and that several instruments prohibit this wrongful international act. Through these cases, the ICJ clarifies that the prohibition is grounded in a widespread international practice and on the opinion juris of states, even though there is no developing reason given by the Court with reference to this issue, which would foster further the development of international law.

Another case rendered by the United States Court of Appeals, confirmed that torture is a violation of jus cogens norms [31]. The case concerned about Sidermans an Argentine family (whose members were permanent residents of the United States) who filed suit against Argentina [31]. His purpose was to recover from torture and the wrongful seizure of his property by Argentine Authority. He was beaten and tortured by ten masked men who acted under the direction of the new government of President Maria Estela Peron (1976). As they were forced to flee from their home country, they sold their property and their business was expropriated. The United States Court of Appeals for the Ninth Circuit held that there might be jurisdiction under the Foreign Sovereign Immunity Act in Siderman de Blake v. Republic of Argentina [30, 722].

The court in recognizing the jus cogens norms held that:

"The right to be free from official torture is fundamental and universal, a right deserving of the highest status under international law, a norm of jus cogens. The crack of the whip, the clamp of a thumb screw, the crush of the iron maiden, and ... the shock of the cattle prod are forms of torture that international order will not tolerate. To subject a person to such horrors is to commit one of the most egregious violations of the personal security and dignity of a human being." [30, 717] 
In case Prosecutor v. Anto Furundzija, of the International Criminal Tribunal of the former Yugoslavia (ICTY) obiter dictum suggestion that the violation of jus cogens norms, such as the prohibition against torture, has direct legal consequences for the legal character of all official domestic relations relating to the violation [30, 58]. It sustained that the absolute prohibition of torture, under conventional and customary international law having the character of jus cogens and generating obligations erga omnes [21] was so absolute that it had incidence not only on actual, but also potential violations. ${ }^{7}$ Though, this case refers to the prohibition of torture, other potential cases which would relate to the challenging of the legality of a prohibited international rule may apply to all other types of crimes which are prohibited by international law. Together with the decision of the Court in Jelisic [23], Kupreskic and Others [24], Kunarac [25] and Krstic [25], the understanding is maintained that genocide, torture and attacks against civilians in armed conflicts are in breach of the jus cogens. ${ }^{8}$

On the other hand, a proficient development associated with jus cogens norms has also been advanced by the Inter-American Court of Human Rights (IACrtHR), which in its decisions in cases: Cantoral Benavides v. Peru, Maritza Urrutia versus Guatemala [7], Hermanos Gomez Paquiyauri v. Peru [13], and Tibi v. Ecuador ${ }^{9}$, it confirmed that torture, inhuman treatment and extra-judicial executions are in breach of the jus cogens; furthermore, in accordance with the extensive reasoning of the IACrtHR in its historical Advisory Opinion on the Juridicial Condition and Rights of Undocumented Migrants ${ }^{10}$, the understanding is advanced that the fundamental principle of equality and non-discrimination has entered into the domain of jus cogens. ${ }^{11}$

7 On this last point, cf. the Judgement of the European Court of Human Rights [ECtHR] in the Soering v. United Kingdom case (1989, para. 144 and 148). And, on the practice under the U.N. Covenant on Civil and Political Rightsm cf. F. Pocar, "Patto Internazionale sui Diritti Civili e Politici ed Estradizione", in Diritti dell' Uomo, Estradizione ed Espulsione - Atti del Convegno di Ferrara (1999) per Salutare G. Battaglini (ed. F. Salerno), Padova, Cedam, 2003, pp. 89-90; Antonio Augusto Cancado Trinidade, International Law for Humankind: Towards a New Jus Gentium, (2010), p. 297.

${ }^{8}$ Cf., e.g., F. Hahoff, "La consecration de la notion de jus cogens dans la jurisprudence des tribunaux penaux itnernationaux", in Actualite de la jurisprudence penale international a l'heure de la mise en place de la Court Penale Internationale (eds. P. Tavernier and C. Renaut), Bruxelles, Bruylant, 2004, pp. 65-80; Antonio Augusto Cancado Trinidade, International Law for Humankind: Towards a New Jus Gentium (2010), p. 297.

9 Case of Tibi v. Ecuador, 2004, IACtHR (September 7).

${ }^{10}$ Advisory Opinion n. 18 on the Juridicial Condition and Rights of Undocumented Migrants, IACtHR, 2003.

11 Advisory Opinion n. 18 on the Juridicial Condition and Rights of Undocumented Migrants, IACtHR, 2003, para. 97-101; See also A. A. Cançado Trinidade, "The case law of Inter-American Court of Human Rights: An Overview", in Studi di Diritto Internazionale in Onore di Gaetano Arangio-Ruiz, vol. III, Napoli, Ed. Scientifica, 2004, pp. 1873-1898; See also: Antonio Augusto Cançado Trinidade. Jus cogens: The determination and the gradual expansion of its material content in contemporary international case-law, pp. 11-12. 
In all of the aforementioned international cases, it is seen that Courts through years have developed further the notion of jus cogens norms, by identifying in some cases precise jus cogens norms and by reaffirming that states are obliged to fulfill their obligations under international law, including rules of international law and for that they remain responsible for any act attributable to them which are contrary to international law in general and international crimes in specific.

\section{Conclusion}

International law has been created largely by the consent of states. The UN as a prominent body in the international society, and the ICJ as a body of the UN, has reaffirmed that states are obliged to fulfill their obligation under international law otherwise they will remain responsible for any act attributable contrary to international law. However, for international law which lacks any legislative power, with no centralized or law-making body, it is too difficult to override binding principles towards states as it cannot impose legal rules. Additionally, the undefined procedure of the creation of peremptory norms by international law is another difficulty in raising conflicting assertions by the international community.

Notwithstanding that peremptory norms are not defined in a specifically manner, it has been shown that international courts in general and the ICJ in specific, are developing and have developed further this notion, by identifying explicitly a number of peremptory norms into their judgments.

Nevertheless, international community should acquire consensus within states, and define precisely jus cogens norms in order not to misuse contrary the concept, or the states together with the international community should call for an international consensus in order to set the legal hierarchical order of the jus cogens norm, taking into account always the development scope of international law. Conversely, jus cogens norms on the one hand put forward a hierarchy between state conflicting interests and, on the other hand, facilitate the world-wide legal order in depriving conflicting international acts visa-verse states.

In endowing with the relation of jus cogens and international law in general, as has been stated by Judge Cancardo on his separate opinion in Belgium v. Senegal case law, where he attributes an ethical content to the new jus gentium, the international law for humankind. He convolutes that in prohibiting torture in any circumstances whatsoever, jus cogens exists indeed for the benefit of human beings, and ultimately of entire humankind. Its development results from "the awakening of the universal juridical conscience". Therefore, these norms not only prevent states from criminal acts, but also human beings as an entire world-wide society.

Overall, consider the established nature of jus cogens norms by all of the international courts which have prohibited the use of force, the prohibition of slavery, torture, inhuman treatment, extra-judicial executions fundamental principle of equality and 
non-discrimination as a domain of peremptory norms, it appears highly unlikely that no State should enter into agreements which conflict with such norms or, at the very least, that they should seize an international tribunal of possible violations of such agreements. Therefore, it is not surprising that in the course of more than fifty years following the entry into force of 1969 Vienna Convention on the Law of Treaties, violations of jus cogens norms have not successfully been relied upon in order to challenge the validity of the treaties.

In conclusion, I put forward my analysis that there should be a harmonized standard or unification among courts in defining jus cogens norms, otherwise courts might be inclined to be using controversial terms of this notion. No doubt, the codification of the VCLT jointly with the jus cogens notion is a remarkable useful source for the international community; however, without concrete developments of these norms, it will be left to the margin of the states to define these norms, which keep the universality of human rights become further protective merely through international court interpretations On the contrary, a unification of jus cogens norms through international law allows us to think that one day all international wrongful acts will become at some point world-wide derogatory.

\section{Vēsturisks pārskats par jus cogens normām, to piemērojamība starptautiskās tiesās un unifikācijas nepieciešamība}

\section{Kopsavilkums}

Šì raksta galvenais mērḳis ir vajadzība standartizēt jus cogens normas, kuras papildus to definīcijai Vīnes konvencijā par starptautisko līgumu tiesībām ir tālāk attīstījušas starptautiskās tiesas. Šis raksts ir sadalīts četrās daḷās, kas ietver jus cogens normu raksturošanu, to attīstību starptautisko tiesību agrākajā vēsturē, šo normu izstrādi starptautiskajās un reǵionālajās tiesās un noslēgumā - nepieciešamību unificēt jus cogens normas.

Raksta noslēgumā iespējams izteikt galvenos secinājumus par analizēto jautājumu. Starptautiskās tiesas, lai nebūtu spiestas izmantot pretrunīgus jus cogens normu terminus, ir aktualizējušas nepieciešamību pēc vienotas sistēmas un šo normu unifikācijas / standartizācijas, lai turpinātu attīstìt jus cogens normas un to piemērošanu.

Atslēgvārdi: jus cogens normas, Vīnes konvencija par starptautisko līgumu tiesībām, starptautiskās tiesības, unifikācija, standartizācija. 
Valeza Ukaj-Elshani. Historical Overview of Jus Cogens Norms,

Their Applicability by International Courts and Necessity for Unification

\section{References}

1. Advisory Opinion OC-18/03, Juridical Condition and Rights of Undocumented Migrants; OC-18/03, Inter-American Court of Human Rights (IACrtHR), 17 September 2003.

2. Bassiouni, M. C. (2011). Crimes against Humanity: Historical Evolution and Contemporary Application. Cambridge: Cambridge University Press.

3. Blackstone, William, Sir, 1723-1780. Commentaries on the Laws of England. In Four Books. By Sir William Blackstone, Knt. One of the Late Justices of His Britannick Majesty's Court of Common Pleas. In Four Volumes. Printed at Worcester, Massachusetts. By Isaiah Thomas, sold at his bookstore in Worcester, and by him and Company in Boston, 1790.

4. Cantoral-Benavides v. Peru, Judgment (IACtHR, 3 Sep. 1998).

5. Case Concerning Armed Activities on the Territory of the Congo (Democratic Republic of the Congo v. Rwanda), International Court of Justice (ICJ), 18 September 2002.

6. Case Concerning Military and Paramilitary Activities in and Against Nicaragua (Nicaragua v. United States of America); Merits, International Court of Justice (ICJ), 27 June 1986.

7. Case of Maritza Urrutia v. Guatemala, Series C No. 103, Inter-American Court of Human Rights (IACrtHR), 27 November 2003.

8. Council of Europe. European Convention for the Protection of Human Rights and Fundamental Freedoms, as amended by Protocols No. 11 and 14, 4 November 1950, ETS 5.

9. Crawford, J., \& Brownlie, I. (2012). Brownlie's Principles of Public International Law.

10. Danilenko, G. M. (1991). International jus cogens: issues of law-making. European Journal of International Law. 21, 42-65.

11. De Wet, E. (2004). The prohibition of torture as an international norm of jus cogens and its implications for national and customary law. EJIL, 15.

12. European Union. (2012). Charter of Fundamental Rights of the European Union, 26 October 2012, 2012/C 326/02.

13. Gomez Paquiyauri v. Peru. (2000). Case 11.015, Inter-Am. C.H.R., Report No. 44/01, OEA / Ser. L/V/II.111, doc. 20, rev.

14. Grotius, H. (1625). The Rights of War and Peace. Edited and with an Introduction by Richard Tuck, from the Edition by Jean Barbeyrac (Indianapolis: Liberty Fund, 2005).

15. Hannikainen, L. (1988). Peremptory Norms (jus cogens) in International Law: Historical Development, Criteria, Present Status. Helsinki, Finnish Lawyers' Pub. Co.

17. IACHR Series C No. 114 (Official Case No.), IHRL 1497 (IACHR 2004).

18. ICJ GL No. 144 (Official Case No.), ICGJ 437 (ICJ 2012).

19. International Committee of the Red Cross (ICRC). Geneva Convention Relative to the Protection of Civilian Persons in Time of War (Fourth Geneva Convention), 12 August 1949, 75 UNTS 287.

20. Oscar Chinn (U.K. v. Belg.), 1934. P.C.I.J. (ser. A/B) No. 63 (Dec. 12).

21. Prosecutor v. Anto Furundzija (Trial Judgement), IT-95-17/1-T. International Criminal Tribunal for the former Yugoslavia (ICTY), 10 December 1998.

22. Prosecutor v. Dragoljub Kunarac, Radomir Kovac and Zoran Vukovic (Trial Judgment), IT-9623-T \& IT-96-23/1-T, International Criminal Tribunal for the former Yugoslavia (ICTY), 22 February 2001.

23. Prosecutor v. Goran Jelisic (Trial Judgement), IT-95-10-T, International Criminal Tribunal for the former Yugoslavia (ICTY), 14 December 1999.

24. Prosecutor v. Kupreskic et al. (Trial Judgement), IT-95-16-T, International Criminal Tribunal for the former Yugoslavia (ICTY), 14 January 2000. 
25. Prosecutor v. Radislav Krstic (Trial Judgement). International Criminal Tribunal for the former Yugoslavia (ICTY), 2 August 2001.

26. Qerimi, Q. (2010). International law and international law of human rights. The Right, 2.

27. Questions relating to the Obligation to Prosecute or Extradite (Belgium v. Senegal), [2009], I.C.J. Reports at 99.

28. Reeves, C. (2012). Natural Law. doi: 10.1093/OBO/9780199796953-0024.

29. S. S. Wimbledon (U.K. v. Japan), 1923 P.C.I.J. (ser. A) No. 1 (Aug. 17).

30. Siderman De Blake v. Republic of Argentina, 965 F.2d 699 (1992), United States Court of Appeals for the Ninth Circuit, 22 May 1992.

31. Soering v. The United Kingdom, 1/1989/161/217, Council of Europe: European Court of Human Rights, 7 July 1989.

32. UN General Assembly. Convention against Torture and Other Cruel, Inhuman or Degrading Treatment or Punishment, 10 December 1984. United Nations, Treaty Series, vol. 1465.

33. UN General Assembly. Convention on the Law of the Sea, 10 December 1982.

34. UN General Assembly. Convention on the Non-Applicability of Statutory Limitations to War Crimes and Crimes against Humanity, 26 November 1968, A/RES/2391(XXIII).

35. UN General Assembly. Convention on the Prevention and Punishment of the Crime of Genocide, 9 December 1948. United Nations, Treaty Series, vol. 78.

36. UN General Assembly. Declaration on the Granting of Independence to Colonial Countries and Peoples. Resolution 1514 / UN GAOR, 15th Sess., Supp. No. 16 / UN Doc. A/4684 (1960) 66.

37. UN General Assembly. Formulation of the principles recognized in the Charter of the Nürnberg Tribunal and in the judgment of the Tribunal, 21 November 1947, A/RES/177.

38. UN General Assembly. International Convention on the Elimination of All Forms of Racial Discrimination, 21 December 1965. United Nations, Treaty Series, vol. 660.

39. UN General Assembly. International Covenant on Civil and Political Rights, 16 December 1966. United Nations, Treaty Series, vol. 999.

40. UN General Assembly. International Covenant on Economic, Social and Cultural Rights, 16 December 1966. United Nations, Treaty Series.

41. UN General Assembly. Question of Western Sahara: resolution / adopted by the General Assembly, 11 December 1991, A/RES/46/67.

42. UN General Assembly. Report of the International Law Commission, A/CN.4/SER.A/1966.

43. UN General Assembly. Rome Statute of the International Criminal Court (last amended 2010), 17 July 1998.

44. UN General Assembly. Universal Declaration of Human Rights, 10 December 1948, 217 A (III).

45. United Kingdom v. Belgium. (1934). P.C.I.J., Ser. A/B, No. 63, at 149-150 (dissenting opinion of Schücking, J.).

46. United Nations. Charter of the United Nations, 24 October 1945, 1 UNTS XVI.

47. United Nations. Vienna Convention on the Law of Treaties, 23 May 1969, United Nations, Treaty Series, vol. 1155.

48. Verdross, A. (1966). Jus Dispositivum and Jus Cogens in International Law. American Journal of International Law. JSTOR, 60(1), p. 55.

49. Verdross, A., \& Garner, J. W. (1937). Forbidden treaties in international law; comments on Professor Garner's report on "The law of treaties". American Journal of International Law. 31, 571-577.

50. Yearbook of the International Law Commission. (1966). Vol. II, ILC. 